\title{
Socialism as Science
}

Kautsky's argument that the socialist perspective and scientific socialism are brought into the labour movement from outside by bourgeois intellectuals, who have taken the proletarian standpoint, seems to display an ambivalence, namely, that the intellectuals ${ }^{1}$ are able to develop scientific socialism precisely because they do not have a clear class position of their own. As a result, not only do they represent higher learning and scientific knowledge, but they also have a specific capacity for abstract thinking. And it seems to be their classless position that endows them with a wider perspective in their thinking: 'However, the intelligentsia is distinguished from both of these classes by its broader intellectual horizons, its better education in how to think abstractly and its lack of united class interests.' ${ }^{2}$ Concrete interests in the daily struggle make it impossible for the other classes in society to understand the general laws of social development, the specific subject matter of scientific socialism. ${ }^{3}$

On the other hand, Kautsky seems to believe that the modern proletariat is the only rightful heir to bourgeois culture [Bildung]. A wage worker has no use for scientific knowledge in improving his social and economic position. He cherishes scientific knowledge for its own sake, like an ancient philosopher:

One of the most striking aspects of modern society is the proletariat's thirst for knowledge. Whereas all other classes seek to dawdle away their

1 In referring to the intellectuals as creators and producers of scientific socialism, Kautsky was clearly using the concept in a narrower sense than when talking about intellectuals as the new middle class having some organisational functions in capitalism. He did not, however, explicitly discuss the different uses of the concept, and he did not therefore make any distinction between critical intellectuals and the intellectuals as a social class.

2 Kautsky $1894-5$ a, p. 76.

3 According to Leineweber, Kautsky's theoretical discussion of the social position of intellectuals was the first Marxist contribution to a class theory of 'intelligentsia' (Leineweber 1977, p. 58). It is interesting to note that Karl Mannheim's famous concept of 'free-floating intelligentsia' [freischwebende Intelligenz] is clearly a further extrapolation of Kautsky's ideas. The classless position of intellectuals is the central theme of Mannheim's theory of intelligentsia in Ideology and Utopia (1960, pp. 136-46). There is, however, an important difference between Kautsky and Mannheim, insofar as in Mannheim's thinking, intellectuals - although situated between classes - do not constitute a new middle class (see Mannheim 196o, p. 139). 
leisure time in the most mindless possible way, the proletariat strives for education [Bildung] with veritable greed ...

And this thirst for knowledge is entirely disinterested. Knowledge cannot help the machine-worker to increase his income. He seeks truth for its own sake, not for material gain. He therefore does not limit himself to a single, smaller domain of knowledge: his eye is on the whole: he seeks to understand the whole of society, the whole world. The most difficult conundrums lure him most, he delights in addressing himself to questions of philosophy and metaphysics. It is often difficult to bring him back down to solid earth from the clouds. ${ }^{4}$

The proletariat is the inheritor of the philosophical spirit of the ancient aristocracy because it is interested in the most general and abstract problems of the world for the sake of pure knowledge. Kautsky's argument is similar to that used in connection with the intellectuals: they too have a wider spiritual horizon. And science - the great science - is something that deals with the general and necessary development of the world and society in particular. The specific interests and needs of the various groups of population are often a hindrance to a correct understanding of these general tendencies and laws.

Scientific socialism has a double role in relation to the proletariat: to make it recognise its common goals and general interests, and to make it possible for the proletariat to reach these goals with maximum efficiency. It is, however, not legitimate to draw any ideals from scientific knowledge. ${ }^{5}$ In this respect, Kautsky made a rather clear neo-Kantian distinction between values and science:

Even Social Democracy, as an organisation of the proletariat in its class struggle, cannot [dispense with] the moral ideal, the moral indignation against exploitation and class rule. But this ideal has nothing whatsoever to do with scientific socialism, which is the scientific examination of the laws of the development and movement of the social organism, for the purpose of knowing the necessary tendencies and aims of the proletarian

4 Kautsky 1934, pp. 156-7 (translation modified BL).

5 For a discussion of the neo-Kantian impact on Marxism, and Kautsky and Bernstein especially, see Colletti 1972, pp. 72-6. The distinction between factual statements [Sachurteile] and value statements [Werturteile] is crucial in the neo-Kantian tradition. It is characteristic in this respect that Karl Vorländer, who in his Kant and Marx of 1911 proposed to unite and supplement historical materialism with Kant, approvingly referred to Kautsky's conception of ethics and science (see Vorländer 1924). 
class struggle ... Science has only to do with the recognition of necessity. It can certainly arrive at prescribing a shall, but this may only come up as a consequence of insight into the necessary. ${ }^{6}$

Science cannot ascribe any ideals or goals to action; it can, however, reveal the direction of development and, hence, the necessary outcome of history.7 In this sense, it can be of assistance in showing that some goals of action are impossible to achieve (i.e. wage workers have no other realistic alternative but socialist society to liberate them from the exploitation of capital). Hence, the unifying role of science is based on the recognition of the laws of development of society: 'Without socialist theory they are not able to recognise the unity of their interests. The individual strata of the proletariat are alien to each other, occasionally even hostile.8 Apart from its role as a unifying force, science can function as a guideline in the struggle for socialism, that is to say, only with the help of science is the proletariat able to reach its historical goals with the maximum efficiency and minimum use of energy:

Only through a recognition of the social process, its tendencies or aims, can this waste be ended, the strength of the proletariat concentrated, the workers brought together into great organisations united around a common aim, with all personalities and momentary actions subordinated to the permanent class interests, and those interests, in turn, placed at the

6 Kautsky 1909b, pp. 202-3. In discussing the limits of science and scientific knowledge, Kautsky also made a distinction between individual and mass phenomena. Only the latter can become the object of scientific study and knowledge: "The field of science only extends as fas as the field of discernible necessity. Where this ends, science ends too. Its frontiers are expanding on a daily basis, but we are not yet far enough to be able to scientifically fathom the will of the individual in society, i.e. to be able to recognise it as necessity. The field of science only extends as far as the field of discernible necessity. We can only subject mass phenomena to scientific investigation' (Kautsky 1900-1, p. 358). It is, however, somewhat unclear whether this distinction is thought to be one of principle, or whether it is a practical limitation due to the present stage of the development of science.

7 Kautsky's discussion of science as revealing the necessity in history was certainly influenced by Engels's conception of freedom and necessity in Anti-Dühring. According to Engels, in socialism humans will consciously make use of the laws governing the development of society. For Engels, then, socialism does not abolish the natural laws of society, but will be equal to the conscious utilisation of these laws in the interest of humanity. 'The laws of his own social action ... will then be used with full understanding, and so mastered by him' (Engels 1974-2004d, pp. 254-71).

8 Kautsky 1919a, p. 29. 
service of collective social evolution. In other words, theory is the factor that raises to the highest degree the strength which it is possible for the proletariat to develop. Theory does this by teaching the workers how to use the powers arising at any given stage of economic development in the most effective manner and by preventing the waste of those powers. ${ }^{9}$

Because the proletariat does not realise its own power in the present society, the analysis of the development of society and the class position of the proletariat is a necessary step on the way to the establishment of proletarian power.

The proletariat is in a more fortunate position than the earlier revolutionary classes in history.$^{10}$ Its science is the most developed form of knowledge. The new science was developed from the proletarian standpoint. Yet, to Kautsky, the proletarian and the scientific standpoint are identical, because the proletariat represents progress in history. In this sense, its general interests are identical to the interests of the whole of society:

But no party has ever delved into the social tendencies of its time so deeply, and understood them as precisely as social democracy has. That is due not to social democracy's merit, as to its good fortune. It owes its superiority to the fact that it stands on the shoulders of bourgeois economy, which carried out the first scientific investigation of social relations and conditions. ${ }^{11}$

The revolutionary proletariat is the rightful heir to this theoretical aspiration, which is dying out with the increasing conservatism and reactionary nature of the bourgeoisie. ${ }^{12}$ The proletariat can and must base its whole action and

$9 \quad$ Kautsky 1919a, p. 44.

10 Cf. also: 'Yet social democracy's great fortune stems from the fact that it has the fortune of possessing a theory that can guide it better than any other through the labyrinth of modern society and shows that its aims point in the same direction as that of necessary social development, whereas those of our opponents go in the opposite direction. Our aims therefore prove to be irresistible, whereas those of our opponents prove to be barren ... But our socialist theory does not merely point out the general direction of social development, but it also makes it possible for us to predict the coming situation, and what this situation demands, with greater certainty than would otherwise be the case. It makes it possible for us to prepare ourselves for such situations, and to exploit them most rapidly and energetically' (Kautsky $1905^{-6}$, p. 859).

11 Kautsky 1910b, p. 123 (translation modified BL).

12 Kautsky 1902-3a, p. 730. 
struggle on scientific knowledge of the laws of society. In this very sense, the proletarian standpoint is the scientific one, and the proletariat the inheritor of the scientific world outlook of the bourgeoisie.

The scientific perspective is synonymous with the recognition of the objective necessary laws of society, and the recognition of these necessities is identical to the general proletarian interest:

And these outlooks are no mere expectations of conditions which simply ought to come, which we simply wish and will, but outlooks at conditions which must come, which are necessary. Certainly not necessary in the fatalist sense, that a higher power will present them to us of itself, but necessary, unavoidable in the sense that the inventors improve technology and the capitalists, in their desire for profit, revolutionise the whole of economic life in its entirety, as it is also inevitable that the workers aim for shorter hours of labour and higher wages, that they organise themselves, that they fight the capitalist class and its state, as it is inevitable that they aim for the conquest of political power and the overthrow of capitalist rule. Socialism is inevitable because the class struggle and the victory of the proletariat is inevitable. ${ }^{13}$

The scientific interest is not, however, identical to the specific interests of the wage workers, and the proletariat cannot come to know the social necessities all by itself in its practical political action. It presupposes that the proletarian science - a new positive science more scientific than its predecessors is developed. ${ }^{14}$ Socialism is inevitable, but only on condition that its inevitability is understood by the proletariat; however, the problem is not unsolvable since the proletariat will inevitably come to understand this inevitability. It has no other alternative. Once the development of society towards greater concentration and polarisation is understood and recognised, the interests of the

13 Kautsky 1910b, p. 206 (translation modified BL).

14 Cf. also: 'As soon as it has arrived at self-consciousness to some extent, an ascendent class, which cannot achieve complete equality or develop freely within the framework of the society in which it is arising, has to strive to replace the existing form of society with another one that suits its interests' (Kautsky 1902-3a, p. 729). Leineweber has suggested an interesting interpretation of such a conception of scientific socialism. The classless socialist science anticipates the future classless society: 'Without knowing it, he [the theoretician] is ideally where the proletarian scatters about in reality' (Leineweber 1977, p. 70). 
proletariat become identical to the demands of progress in society, and the coalition of science and proletariat is accomplished.

Kautsky's comment on the discussion about Mach and Machism ${ }^{15}$ - a lively discussion among Marxists of his time, as shown also by Lenin's Materialism and Empirio-criticism ${ }^{16}$ - is typical both of his willingness to avoid any disputes which would endanger the unity of the party and which in his opinion are also totally irrelevant from the point of view of social theory and practical politics. For Kautsky, Marxism was essentially a positive science of society and of history, and it did not include any specific theory of knowledge. Even though materialism is characteristic of Marxism, questions of the theory of knowledge are irrelevant to Marxism, and the stand adopted by a Marxist on these questions is exclusively a private matter for every individual member of the party.

The main task of the proletariat is to learn Marxist theory of capitalism and the materialist conception of history, and especially to recognise the immediate tasks in its own country. Compared with these main truths of Marxism, the theoretical clarity about different versions of the theory of knowledge is of secondary importance. ${ }^{17}$

\footnotetext{
15 Kautsky 1909a.

16 Lenin 1967i.

17 In this respect, Lenin's position could be characterised as a total antithesis. In his opinion, questions concerning the theory of knowledge are of immediate interest to the party. Il'enkov (1980) accordingly interpreted the importance of Lenin's Materialism and Empirio-criticism mainly from the point of view of the political line of the Russian Social Democratic Party: the main result of Lenin's critique of Mach's theory of knowledge is that a Menshevik having a false conception of the strategy of the party but a correct position in the theory of knowledge is less dangerous than a Bolshevik representing a Machist theory of knowledge.
} 